\title{
Leveraging differences in multiple prey traits allows selective copepods to meet their threshold elemental ratios
}

\author{
Emily Herstoff ${ }^{1}$, Cédric Meunier ${ }^{2}$, Maarten Boersma ${ }^{3}$, and Stephen Baines ${ }^{4}$ \\ ${ }^{1}$ The College of New Jersey \\ ${ }^{2}$ Alfred-Wegener-Institut \\ ${ }^{3}$ Alfred-Wegener-Institut Helmholtz-Zentrum für Polar- und Meeresforschung \\ ${ }^{4}$ Stony Brook University College of Arts and Sciences
}

June 16, 2020

\begin{abstract}
Foraging based on prey elemental content could be more pronounced if consumers leveraged differences in physical traits among stoichiometrically distinct prey to ingest more favorable food, allowing consumers to meet their threshold elemental ratios (TER). We offered the marine copepod, Acartia tonsa, different combinations of large and small diatom congeners, grown to be either stoichiometrically replete or nitrogen-deficient. When offered each diatom alone, A. tonsa exhibited compensatory grazing on large diatoms, and ingested more nitrogen-deficient cells. When offered diatoms that differed in both size and stoichiometry, copepods mixed their diets to achieve a C:N close to their independently estimated optimal TER. When offered pairs of different-sized diatoms of similar stoichiometry, A. tonsa preferred larger cells, suggesting evolutionary constraints drive choice when stoichiometric differences are minimal. Experiments describing selectivity on single traits may seriously underestimate how precisely copepods can optimize their dietary stoichiometry when feeding on a diverse natural prey assemblage.
\end{abstract}

\section{TITLE:}

Leveraging differences in multiple prey traits allows selective copepods to meet their threshold elemental ratios

\section{AUTHORS:}

Emily M. Herstoff ${ }^{1,2}$, Cédric L. Meunier ${ }^{3}$, Maarten Boersma ${ }^{3,4}$, Stephen B. Baines ${ }^{2}$

1. Biology Department, The College of New Jersey, emily.herstoff@alumni.stonybrook.edu 2. Department of Ecology \& Evolution, Stony Brook University, stephen.baines@stonybrook.edu 3. Alfred-Wegener-Institut Helmholtz-Zentrum für Polar- und Meeresforschung, Biologische Anstalt Helgoland, Helgoland, Germany maarten.boersma@awi.de cedric.meunier@awi.de 4. University of Bremen, FB2, Bremen, Germany

\section{RUNNING TITLE:}

Copepods meet TER by leveraging prey traits (43 of 45 allowed characters, including spaces)

\section{KEYWORDS:}

Acartia tonsa, ecological stoichiometry, selectivity, copepod, optimal foraging, threshold elemental ratio, prey choice, nutritional geometry

ARTICLE TYPE: Letter

WORD COUNT: 
Abstract: 150 out of 150 allowed Main text: 4738 out of 5000 allowed

NUMBER OF REFERENCES: 72

NUMBER OF FIGURES: 4

NUMBER OF TABLES: 2

NUMBER OF TEXT BOXES:0

CORRESPONDANCE:

Stephen B. Baines Dept. of Ecology and Evolution, Life Sciences Building Stony Brook University Stony Brook, NY 11794 E-mail: stephen.baines@stonybrook.edu Phone: (631) 632-1092 Fax: (631) 632-7626

\title{
AUTHOR CONTRIBUTION
}

All co-authors contributed to the design of the experiment. EMH conducted the experiments and collected and analyzed data on cell ingestion. CLM and MB collected data on diatom stoichiometry. SBB provided lab space and equipment. All authors contributed to the interpretation of the data and to the writing of the manuscript.

\section{DATA ACESSIBILITY}

Should this manuscript me accepted, the supporting data will be archived in FigShare, and the DOI will be provided at the end of this article.

\begin{abstract}
Foraging based on prey elemental content could be more pronounced if consumers leveraged differences in physical traits among stoichiometrically distinct prey to ingest more favorable food, allowing consumers to meet their threshold elemental ratios (TER). We offered the marine copepod, Acartia tonsa, different combinations of large and small diatom congeners, grown to be either stoichiometrically replete or nitrogendeficient. When offered each diatom alone, A. tonsa exhibited compensatory grazing on large diatoms, and ingested more nitrogen-deficient cells. When offered diatoms that differed in both size and stoichiometry, copepods mixed their diets to achieve a C:N close to their independently estimated optimal TER. When offered pairs of different-sized diatoms of similar stoichiometry, A. tonsapreferred larger cells, suggesting evolutionary constraints drive choice when stoichiometric differences are minimal. Experiments describing selectivity on single traits may seriously underestimate how precisely copepods can optimize their dietary stoichiometry when feeding on a diverse natural prey assemblage.
\end{abstract}

\section{INTRODUCTION}

Primary consumers have specific dietary needs based on demands for growth and reproduction, which suggests that they should possess the ability to optimize dietary intake of key nutrients. Optimal foraging theory posits that consumers should be selective and preferentially ingest high-quality prey; low-quality prey may also be consumed, depending on the costs of prey rejection and the availability of high-quality prey (Lehman 1976, DeMott 1989). Although optimal foraging theory was originally developed considering energetic cost/benefits to consumers (e.g., Emlen 1966, MacArthur and Pianka 1966, Krebs et al. 1977), this theory can be extended to consider a consumer's other nutritional cost/benefits as well, as has been studied using nutritional geometry and ecological stoichiometry (Raubenheimer and Simpson 1997, 2004, Sterner and Elser 2002, Simpson et al. 2004, Simpson and Raubenheimer 2011). Within these ecological frameworks, organisms are expected to ingest food of varying qualities in proportions that will maximize their fitness. Therefore, consumers may be expected to use selective feeding to consume prey that allows the consumer to reach its target intake, in terms of nutritional geometry, or its threshold elemental ratio (TER), in terms of ecological stoichiometry, to maximize growth and production (Urabe and Watanabe 1992, Simpson et al. 2004, Frost et al. 2006, Simpson and Raubenheimer 2011). 
Copepods are the most abundant metazoans on Earth (Turner 2004), so it is important to understand how their selective feeding affects the stoichiometry of their diet. The copepod's growth influences the ecological efficiency of aquatic food webs (Wishner et al. 1988, Lavigne 2003, Laidre et al. 2007, Mitra et al. 2014), and their diet determines elemental ratios in recycled, suspended, and sinking material (e.g., Elser et al. 1996, Steinberg et al. 2002, Meunier et al. 2016, Franco-Santos et al. 2018). Choice and behavior experiments show that copepods differentiate between prey of the same species but different stoichiometry (Cowles et al. 1988, Butler et al. 1989, Meunier et al. 2016, Herstoff et al. 2019, but see Isari et al. 2013). However, copepods do not display perfect selectivity in these experiments, and often consume some amount of stoichiometrically 'less-preferable' prey as a result (e.g., Meunier et al. 2016). This can make it hard for consumers to match their optimal TER, and can reduce the consumer's potential for production (Plath and Boersma 2001, Boersma and Elser 2006, Zhou and Declerck 2019). Therefore, patterns of consumer selectivity in nature may reflect other prey traits independent of stoichiometry, such as prey detectability as it varies with size or motility. For example, copepods select between prey based on cell size (Mullin 1963, Richman and Rogers 1969, Frost 1972, Berggreen et al. 1988, Hansen et al. 1994), and can preferentially remove their preferred prey type, even if it is rare within the environment (Stoecker and Sanders 1985, Jakobsen et al. 2005). However, while we know that multiple, individual traits influence selectivity, we still do not know how copepod choice is influenced by simultaneous differences in multiple prey traits, particularly when traits differ between prey species.

Choice experiments involving single prey species may underestimate how effectively copepods can achieve an optimal dietary stoichiometry in nature. Numerous traits that copepods can use to feed discriminately, including stoichiometry, often covary in natural prey communities (Quigg et al. 2003, Finkel et al. 2009). Some copepods switch foraging modes to selectively target prey of a certain size and motility (Kiørboe et al. 1996, Kiørboe 2011, Saiz et al. 2014). If prey of different size, for example, also differ in elemental content, copepods might be able to switch feeding modes to target the stoichiometrically more favorable prey or to switch back and forth between modes to achieve an optimal diet mixture. Indeed, elemental and biochemical composition of phytoplankton is often related to traits such as size or motility, which are themselves functions of evolutionary history, functional adaptations, and ecological strategy (Litchman et al. 2010, Meunier et al. 2017). Thus, the correlation between the physical characteristics that consumers act upon and the nutritional quality of autotrophic prey is likely an important feature of aquatic primary producer communities (Sterner and Elser 2002, Finkel et al. 2009, Hall 2009) that may help consumers meet their TER more effectively.

Alternatively, if food quality is uniformly poor, zooplankton may simply alter ingestion to maximize their intake of energy or key limiting nutrient elements, depending on which one is most limiting to copepod growth, and which one is most costly to dispose of. While selectivity best allows consumers to choose prey that most closely meet their TER, this will not be possible when faced with a monoculture of poor-quality prey, as may be the case in low nutrient waters or at the culmination of phytoplankton blooms. In situations like this, some consumers can engage in compensatory feeding to maximize ingestion of limiting nutrients (e.g., Libourel Houde and Roman 1987, Meunier et al. 2012). The ratio of carbon to other elements of phytoplankton prey can vary with access to light, carbon dioxide, and nutrients, as well as the existence of structural materials, the ability to engage in luxury uptake, and the storage of compounds (Sterner and Elser 2002, Ågren 2004, Frost et al. 2005, Meunier et al. 2014). Provided the costs of regulating excess carbon to other elements are not too great (Boersma and Elser 2006), or using the excess carbon to increase the uptake of the limiting nutrient (Plath and Boersma 2001), this strategy may favor consumers that use compensatory feeding when only poor-quality food is available.

We addressed three questions by offering adult female $A$. tonsavarious combinations of two genetically closely related, differently-sized species of marine diatoms that had been grown in either nutrient replete or nutrientdeficient media. First, we asked when there was a strong contrast in diatom size and elemental content in a mixture, can copepods reach their predicted optimal TER by leveraging prey size to target prey based on its stoichiometry? Second, we asked when the only food offered to them is nutrient-poor, does $A$. tonsa exhibit evidence of compensatory grazing? Last, based on these experiments, we asked when diatom size differs but stoichiometric differences between prey are minimal, do copepods engage in simple, size-based selectivity 
and target larger, more carbon-rich diatoms to optimize energy uptake? We found that A. tonsa exhibits a high degree of plasticity in its preference, and will ingest a mixture of prey to achieve a C:N ratio close to its theoretical TER when those prey differ strongly in both size and quality. We hypothesize that copepods in natural systems may therefore leverage different prey traits to consume a prey mixture that matches their TER, as predicted by the framework of nutritional geometry. We suggest that choice experiments involving single prey traits may underestimate the impact of consumer selectivity on ecosystem process when prey communities are complex.

\section{MATERIALS AND METHODS}

\section{Organism Husbandry}

We used the centric diatoms Thalassiosira weissflogii and T. pseudonana (class: Mediophyceae) as prey. These congeners are of different sizes (T. pseudonana : ${ }^{\sim} 4.15 \mu \mathrm{m}$ equivalent spherical diameter (ESD); $T$. weissflogii : $13 \mu \mathrm{m} \mathrm{ESD),} \mathrm{can} \mathrm{be} \mathrm{grown} \mathrm{to} \mathrm{have} \mathrm{different} \mathrm{stoichiometries,} \mathrm{and} \mathrm{are} \mathrm{both} \mathrm{readily} \mathrm{consumed}$ by Acartia tonsa(e.g., Miller and Roman 2008, Siuda and Dam 2010, Tyrell and Fisher 2019). While larger diatoms contain more nutrients, such as carbon $(\mathrm{C})$ and nitrogen $(\mathrm{N})$, per cell than do smaller diatoms (Strathmann 1967, Montagnes and Franklin 2001), C assimilation efficiency is greater for Acartia copepods consuming smaller diatoms like T. pseudonana, as opposed to larger diatoms like T. weissflogii (Xu and Wang 2003), even though smaller diatoms are typically not grazed as efficiently as larger cells (Støttrup and Jensen 1990).

Diatoms were grown in semi-continuous $2 \mathrm{~L}$ cultures in artificial seawater created by dissolving 30 ppt Red Sea Salt ${ }^{\mathrm{TM}}$ (Red Sea USA, Houston, Texas) in MilliQ water, aerating the mixture for at least 24 hours, and then filtering at $0.2 \mu \mathrm{m}$ before use. Diatoms were kept at $18^{\circ} \mathrm{C}$ under $254 \mu$ Einsteins $\mathrm{m}^{-2} \mathrm{~s}^{-2}$ on a 12:12 light:dark regime. Diatoms were grown to be either nutrient replete (amended with $\mathrm{f} / 2$ levels of nutrients, as per Guillard and Ryther 1962), or to be N-deficient (f/200 level of $\mathrm{NO}_{3}{ }^{-}$added). We focused on nitrogen content in our experiments because N-rich prey allows better somatic growth and egg production in copepods (Franco-Santos et al. 2018), and because older A. tonsa selectively consume N-rich food (Meunier et al. 2016), and exhibit more feeding behavior when offered N-rich prey (Herstoff et al. 2019).

Diatom culture density and cell sizes were measured daily with a Beckman Multisizer 3 Coulter Counter

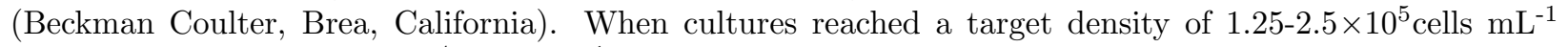

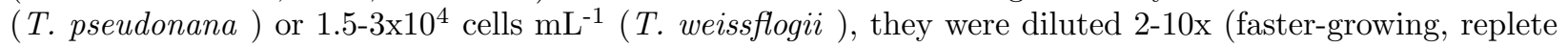
cultures were diluted more). Three replicate samples for C:N analysis were collected on the morning of the grazing experiments by filtration at $<5$ psi vacuum onto glass fiber filters (Whatman GF/F). Samples were dried at $60 \operatorname{deg} \mathrm{C}$, and $\mathrm{C}$ and $\mathrm{N}$ measured using a Vario Micro Cube elemental analyzer (Elementar, Hanau, Germany).

Measurements of diatom size and stoichiometry were inspected for heteroskedasticity, log-transformed to ensure normality, and analyzed with a one-way ANOVA and post-hoc Tukey HSD tests (Sokal and Rohlf 2012) using $\mathrm{R}$ (The R Core Team 2013). Thalassiosira weissflogii was significantly larger than T. pseudonana , regardless of stoichiometric rearing condition (Table 1). While $\mathrm{C}$ content differed between the two diatom species, C content did not differ within diatoms reared in different stoichiometric conditions (Table 1). Within each of the two diatom species, cells reared in N-deficient media had significantly lower $\mathrm{N}$, and higher C:N (Table 1). C:N did not differ between the two diatom species grown in N-deficient conditions, but for diatoms grown in replete conditions, T. pseudonana had a significantly higher C:N than T. weissflogii (Table 1). The C:N of small, replete T. pseudonana nearly matched A. tonsa 's predicted optimal TER of 7.12 C:N (Anderson et al. 2017). In contrast, all N-deficient diatoms had much higher C:N, and the large, replete diatoms had slightly lower C:N (Table 1) compared to A. tonsa 's predicted optimal TER of 7.12 C:N (Anderson et al. 2017).

Acartia tonsa cultures were purchased from AlgaGen, LLC (Vero Beach, Florida,) and maintained in the dark at a density of $~ 500$ animals $\mathrm{L}^{-1}$ in $3.5 \mathrm{~L}$ artificial seawater. Water was changed daily, and copepods 
were fed ad libitum with equal parts replete and N-deficient T. weissflogiiand T. pseudonana, and the cryptophyte Rhodomonas salinagrown in $\mathrm{f} / 2$ media.

\section{Experimental Setup}

The experiment consisted of eight treatments run simultaneously that were intended to make three types of comparisons (Fig. 1). In four treatments, we offered copepods each of the four prey types singly to determine reference grazing rates in the absence of selection. In two other treatments, copepods were offered pairs of large and small diatoms, each from different rearing conditions, in two different treatments, to determine if copepods could switch between prey of different size based on their cellular C:N. Last, in two treatments, we offered copepods pairs of large and small diatoms from the same nutrient rearing condition, either stoichiometrically replete or N-deficient, to assess size-selectivity. We did not conduct stoichiometricselective grazing trials because such selectivity has already been shown in numerous studies (e.g., Cowles et al. 1988, Boersma et al. 2016, Meunier et al. 2016).

The experiment was run in the dark on a plankton wheel $(\sim 1 \mathrm{rpm})$ in $225 \mathrm{~mL}$ Falcon ${ }^{\mathrm{TM}}$ polypropylene centrifuge tubes (Corning Incorporated, Corning, New York) for 24 hours. Due to space constraints on the plankton wheel, we could only accommodate three replicates of each treatment at a single time. To increase replication, the experiment was repeated on three separate dates (July 26-27, July 30-31, and August 12,2018 ) to yield nine total replicates for each of the three grazing trials. To determine whether there were significant differences in $\mathrm{C}$ and $\mathrm{N}$ ingestion between the three experiment dates, we added $1 \mathrm{e}^{-10}$ to all measurements to account for the lack of ingestion in some treatments, and then we log-transformed these values to render them normal and homogenize variance. These data were analyzed with a nested ANOVA (Sokal and Rohlf 2012) in R (The R Core Team 2013) using the package nlme (Pinheiro et al. 2020). In the nested ANOVA, day was treated as a random variable, nested within treatment. We determined that there were no significant differences in either $\mathrm{C}$ ingestion $\left(\mathrm{F}_{2,103}=1.89, p=0.16\right)$ or $\mathrm{N}$ ingestion $\left(\mathrm{F}_{2,103}=\right.$ $1.94, p=0.15)$ within similar treatments run on different dates. Because of this, and because all experiments were run close to each other in time, and used the same media, we treated the nine measurements as true replicates. We also ran controls to measure algae growth during the experiment, using tubes that only contained phytoplankton (Frost 1972). All grazing trial tubes contained 10 adult female A. tonsaand their associated diatom prey (Fig. 1). An initial $10 \mathrm{~mL}$ sample was taken from each tube immediately after adding copepods and preserved with Lugol's Iodine for later cell count analysis. After $24 \mathrm{~h}$, a final $10 \mathrm{~mL}$ sample was taken from each tube and preserved with Lugol's Iodine for later cell count analysis.

\section{Data analysis}

We calculated ingestion using the equations in Frost (1972). By multiplying the number of cells ingested by each diatom type's nutritional content, we determined the ingested $\mathrm{C}$ and $\mathrm{N}\left(\mu \mathrm{g} \operatorname{copepod}^{-1} \mathrm{~h}^{-1}\right)$, and the overall C:N (mol:mol) ingested. Comparing $\mathrm{C}$ and $\mathrm{N}$ ingestion allowed us to assess selectivity on the two diatom species despite the $\sim 15$-fold difference cell size, as calculated by cell volume, and the difference in diatom abundance in mixtures, where the smaller T. pseudonana was $\sim 2.5$-fold more abundant than the larger T. weissflogii . In cases where we calculated negative cell ingestion for a particular diatom type, we set ingestion to zero. This happened consistently, in eight of the nine measurements of small, replete diatoms in the size-selective grazing trials, and in all nine measurements of large, $\mathrm{N}$-deficient diatoms in the size $\times$ stoichiometry grazing trials.

In all three grazing trials, we wanted to test if the observed outcomes matched predicted differences based on our hypotheses. We investigated (1) in single-species grazing trials, whether $A$. tonsa would use compensatory grazing to ingest similar amounts of $\mathrm{N}$ when each diatom species from each nutrient condition was offered alone. We predicted that $(2)$ in size $\times$ stoichiometry grazing trials, where there was a strong contrast in both diatom size and $\mathrm{C}: \mathrm{N}$, whether $A$. tonsawould selectively remove mixtures of diatoms to optimize their elemental intake as closely as possible to their TER; and (3) in size-selective grazing trials, where diatom size strongly contrasted but stoichiometric differences were minimal, whether $A$. tonsa would use selectively remove the larger, more C- and energy-rich diatom in the mixture, regardless of the quality of the diatom pair. 
Because we planned to perform a series of comparisons to test these specific predicted results, we performed Welch's t-tests on these focal groups. Welch's t-test allows for unequal variance, which is important because we anticipated there may be more variance in counting the larger, rarer T. weissflogii on the Coulter Counter, as compared to the smaller, more abundant T. pseudonana .

For both the size $\times$ stoichiometry grazing trials and the size-selective grazing trials, we used two-sample Student's t-tests to compare the overall C:N ingested during the course of the choice experiments to the average $\mathrm{C}: \mathrm{N}$ of each diatom type by itself. This allowed us to determine which diatom type was contributing more stoichiometrically to the copepod's diet. For both the size-selective grazing trials and the size $\times$ stoichiometry grazing trials, we used $\mathrm{C}$ ingestion rates for each diatom type within a pair to calculate prey preference using Chesson's selectivity index, $\alpha$ (Chesson 1978, 1983). We then used a $t$-test to compare the observed $\alpha$ in trials to $\alpha=0.5$ (no selectivity).

\section{RESULTS}

\section{Single species grazing trials}

When offered one diatom type at a time, adult female $A$. tonsaexhibited roughly similar average ingestion rates for the two diatom species (average ingestion of $T$. weissflogii $=1120$ cells copepod $^{-1} \mathrm{~h}^{-1}$, of $T$. pseudonana $=1320$ cells copepod ${ }^{-1} \mathrm{~h}^{-1}$ ) although there was some variation among nutrient treatments. This meant that the amount of $\mathrm{C}$ and $\mathrm{N}$ consumed $\left(\mu \mathrm{g} \mathrm{copepod}^{-1} \mathrm{~h}^{-1}\right)$ from T. weissflogii was $\sim 12$-fold and $\sim$ 8.6fold greater than T. pseudonana, because the amount of $\mathrm{C}$ and $\mathrm{N}$ associated with large diatoms was much greater than for small diatoms.

The copepods exhibited some compensatory grazing in these experiments. When offered the large diatom, ingestion was 3.4-fold higher on N-deficient diatoms as compared to replete cells ( $p=0.023$; Table 2; Fig. $2 \mathrm{C})$. Consequently, the copepods obtained significantly more $\mathrm{C}(p=0.032)$ but not significantly more $\mathrm{N}(p$ $=0.98$ ), from N-deficient T. weissflogii as compared to replete T. weissflogii (Table 2, Figs. 2A-2B). For the small diatom, T. pseudonana, cell ingestion rates were essentially identical on replete and N-deficient cells $(p=0.31$; Table 2, Fig. 2C).

\section{Size $\times$ stoichiometry grazing trials}

The copepods in our grazing trials selectively consumed diatom mixtures to match their C:N intake to Anderson et al.'s (2017) predicted optimal TER of 7.12 (Table 2; Figs. 3A-3C \& 4A-4B). Adult female $A$. tonsa showed a distinct preference for replete $T$. pseudonanawhen it was offered in combination with N-deficient T. weissflogii (Table 2, Figs. 3A-3C \& 4A-4B). In this trial mixture, the small, replete diatoms closely match the predicted optimal TER, whereas the large, N-deficient diatoms were above the optimal TER (Table 1). Matching what may be predicted based on the diatom's stoichiometry, we observed that N-deficient T. weissflogii were completely avoided, and replete $T$. pseudonana were exclusively consumed (Table 2, Figs. 3A-3C \& 4A-4B). The cell ingestion rate for replete T. pseudonana was 5.92-fold greater than for the same cell type when offered singly (Figs. $2 \mathrm{C} \& 3 \mathrm{C}$ ). As a consequence, copepods ingested all of their $\mathrm{C}$ and $\mathrm{N}$ from the small diatom in the mixture $(\mathrm{C}: p=0.016 ; \mathrm{N}: p=0.011)$, even though $T$. pseudonana only comprised 0.14-fold the $\mathrm{C}$, and 0.23-fold the $\mathrm{N}$ available, as compared to the larger T. weissflogii . Because replete T. pseudonana was the only diatom consumed, the overall C:N ingestion matched that of the replete T. pseudonana (Fig. 4A; average C:N = 7.13), and Chesson's $\alpha$ measured perfect selection for $T$. pseudonana (Fig. $4 \mathrm{~B} ; \alpha=1$, d.f. $=8, p=0$ ).

In the other trial mixture, the copepods again selectively grazed diatom mixtures to match their C:N intake to Anderson et al.'s (2017) predicted optimal TER of 7.12. In this case, copepods removed both diatom types offered (Table 2; Figs. 3A-3C \& 4A-4B). Compared to the copepod's predicted optimal TER, the small, N-deficient diatom was too C-rich, and the large, replete diatom too C-poor (Table 1). Here, $A$. tonsapreferentially removed smaller, N-deficient T. pseudonana when it was offered in combination with larger, replete T. weissflogii (Table 2; Figs. 3A-3C \& 4A-4B). In this diatom mixture, the cell ingestion rate was 8.16-fold higher for $\mathrm{N}$-depleted T. pseudonanacompared to replete $T$. weissflogii $(\mathrm{t}=4.93$, d.f. $=16$, 
$p<0.0001$ ), and fully 4.68-fold greater than when N-deficient T. pseudonana was offered singly (Figs. 2C \& $3 \mathrm{C} ; t=-7.70$, d.f. $=16, p<0.0001)$. Despite the lower ingestion rate on the larger diatom, adult female A. tonsaobtained more $\mathrm{C}$ and $\mathrm{N}$ from the replete T. weissflogii because this species accounted for $\sim 70 \%$ of the $\mathrm{C}$ and $\mathrm{N}$ in available prey, which resulted in copepods obtaining more $\mathrm{C}$ from $T$. pseudonana (Fig. $4 \mathrm{~B} ; \alpha$ T. pseudonana $=0.73, \mathrm{t}=2.39$, d.f. $=8, p=0.044$ ). Consuming both types of diatoms resulted in copepods ingesting an overall C:N that was intermediate between the replete $T$. weissflogii and the N-deficient $T$. pseudonana (Fig. 4A; average $\mathrm{C}: \mathrm{N}=6.94 \pm 0.53$ ), and closely matched the predicted optimal TER for $A$. tonsa(Anderson et al. 2017).

\section{Size-selective grazing trials}

When offered different-sized cells that had relatively small differences in cellular C:N, adult female Acartia tonsa consumed both diatom types, but ultimately consumed much more of the larger, less abundant, and more C- and N-rich diatom within the pair (Table 2; Figs. 3D-3F), resulting in selective removal of $T$. weissflogii within the mixture (Figs. 4C-4D). When offered pairs of N-deficient diatoms, the larger diatoms were grazed marginally more than small diatoms (Fig. 3F; $p=0.076$ ), and $A$. tonsa consumed 2.74-fold more T. weissflogii in this mixture. When offered pairs of replete diatoms, there was a significantly more grazing on larger diatoms (Fig. 3F; $p=0.0091$ ), and very few T. pseudonana were consumed overall. As compared to T. pseudonana, T. weissflogiiaccounted for 5.11 to 7.66 times the $\mathrm{C}$, and 4.86 to 10.55 times the $\mathrm{N}$ in both the $\mathrm{N}$-deficient and replete experiments, respectively. Therefore, $A$. tonsa obtained almost all of its $\mathrm{C}$ and $\mathrm{N}$ from T. weissflogii in both the N-deficient diatom mixture (Table 2; Figs. 3D \& 3E, C: $p=0.0068$; $\mathrm{N}: p=0.0069$ ), and in the replete diatom mixture (Table 2; Figs. 3D \& 3E, C: $p<0.0001 ; \mathrm{N}: p<0.0001$ ).

Due to these grazing patterns, the C:N of the copepod's diet did not differ from the C:N of T. weissflogii , either when offered replete cells $(t=0.32$, d.f. $=15, p=0.75$; Fig. $4 \mathrm{C})$, or when offered N-deficient cells $(t$ $=-0.77$, d.f. $=16, p=0.45$; Fig. $4 \mathrm{C}$ ). Additionally, we observed strong preferential removal of $T$. weissflogii using Chesson's $\alpha$, both when offered pairs of N-deficient diatoms (Fig. $4 \mathrm{D} ; \alpha=0.97 ; t=184.45$, d.f. $=8, p$ $<0.0001$ ), and when offered pairs of replete diatoms (Fig. 4D; $\alpha=0.89 ; t=7200.94$, d.f. $=8, p<0.0001$ ).

As in the single species grazing trials, there was evidence of compensatory feeding by the adult female $A$. tonsa in these size-selective grazing trials. The higher cell ingestion rate in trials with $\mathrm{N}$-deficient diatoms (Fig. 3F), and particularly the greater ingestion of large diatoms (Fig. 4D) resulted in essentially equivalent $\mathrm{N}$-ingestion (Table 2, Fig. 3E, $p=0.16$ ), whereas the $\mathrm{C}$ ingestion differed by nearly three-fold (Table 2, Fig. $3 \mathrm{D}, p=2.01 \mathrm{e}-04)$.

In summary, when offered diatoms singly, adult female $A$. tonsaengaged in compensatory feeding only with the large diatoms, although the overall cell ingestion rate was low (Fig. 2). Next, during size $\times$ stoichiometry grazing trials, when $A$. tonsa were simultaneously offered small and large diatoms that differed in elemental content, the copepods preferred the smaller diatom species, whether it was N-replete or N-depleted (Fig. 3A-3C; Fig. 4B). In these treatments, the final C:N ingested was indistinguishable no matter which diatom was N-rich $(t=-0.51$, d.f. $=16, p=0.61$; Fig. $4 \mathrm{~A})$, and very close to the TER. Last, during size-selective grazing trials, the copepods that were offered diatoms that differed in size but were similar in C:N preferred the larger diatom, which accounted for more biomass and was nutritionally- and energetically-superior on a cell-by-cell basis (Fig. 3D-F; Fig. 4D).

\section{DISCUSSION}

Our study is the first to show that copepods can actively and effectively reach their TER by leveraging size differences in nutritionally distinct prey. Previous studies have typically focused on selectivity based on one prey characteristic or another, so as to unambiguously identify those traits that control selectivity (e.g., DeMott 1989). Some of these preferences reflect needs, such as prey stoichiometry or fatty acid content, which influence the consumer's growth and reproduction (Klein Breteler et al. 2005, Malzahn and Boersma 2012, Meunier et al. 2016). Others, like preference for prey of a certain size or mobility, are presumed to reflect ease of prey detection, capture, and processing (Frost 1972, Kiørboe et al. 1996, Jakobsen et al. 
2005, Meunier et al. 2013, Saiz et al. 2014). Often, selectivity is thought to be a linear combination of these seemingly independent types of preferences (Wirtz 2012, Litchman et al. 2013). However, some copepods can adjust their feeding strategies or modes while foraging (Kiørboe et al. 1996, Kiørboe 2011, Saiz et al. 2014), which may help them reach their TER by targeting physically distinct prey forms that are in some way nutritionally distinct. We built on prior studies to ask whether such flexibility granted copepods greater leeway to manage the stoichiometry of their diet when feeding on a diverse prey assemblage.

Our results suggest that factors governing size-selective predation are complex. The patterns of selectivity observed in size $\times$ stoichiometry grazing trials indicated that the copepods distinguished between prey that differed in multiple traits, and that the copepods leveraged these differences to match their TER by grazing diatoms in different amounts in both treatments. These observations are in line with the theory of nutritional geometry (Raubenheimer and Simpson 2004, Raubenheimer and Jones 2006, Simpson and Raubenheimer 2011), because copepods mixed their prey intake in different ways to obtain their target C:N. Because consuming food with an excess of particular nutrients can be deleterious to consumers (Boersma and Elser 2006, Tao et al. 2014), some consumers may ingest a mixture of prey types with different stoichiometric imbalances compared to the consumer's requirements. When combined, these different deficiencies in prey stoichiometry may allow the consumer to still reach its target stoichiometry (Simpson and Raubenheimer 2011) and approach the consumer's TER (Anderson et al. 2017). Replete T. pseudonana, which comprised the entirety of the diet in one treatment, had almost the same C:N ratio as the ingested mixture of $\mathrm{N}-$ deficient $T$. pseudonana and replete T. weissflogii in the other, and very closely match the predicted optimal TER for A. tonsa (Anderson et al. 2017). This selective removal of such a large proportion of small diatoms in these treatments indicates that $A$. tonsa may have needed to change its foraging strategies to obtain an optimal overall C:N, even if it meant consuming some prey items that, when offered alone, would have non-preferred stoichiometric or physical characteristics. Although T. pseudonana is not typically grazed very efficiently due to its small size (Støttrup and Jensen 1990), its more desirable stoichiometric content under replete conditions seems to have lead copepods to target this diatom species exclusively, presumably by using suspension feeding (Hansen et al. 1994), and to actively reject any encountered T. weissflogii (Poulet and Marsot 1978, Huntley et al. 1983).

However, when prey differ most strongly in only one important trait, such as size, we observed that $A$. tonsa engaged in simple, size-based selectivity. The copepods likely chose larger prey based on its greater energetic yield, rather than engaging in mixed grazing strategies. Consistent with previous studies of size selectivity in copepods (e.g., Mullin 1963, Richman and Rogers 1969), we observed that adult female A. tonsa selectively removed the larger diatom offered within a pair, despite the smaller diatom sometimes better matching the copepod's predicted optimal TER (Anderson et al. 2017). When faced with a stoichiometrically-similar food source, A. tonsa may be evolutionarily constrained to maximize energy- and nutrient-intake, here, by selectively consuming the larger cells. Thus, the active choices that copepods make can differ in response to multiple prey traits such that simple selectivity experiments may underestimate a consumer's agency in prey selectivity. Furthermore, selectivity experiments that manipulate single prey characteristics may underestimate the importance of consumer selectivity on ecosystem process when prey communities are complex.

When consumers selectively remove prey with particular C:N, the overall stoichiometric content of the remaining prey community will shift. This could have numerous important consequences, such as changing the availability of specific prey for other consumers, or changing the rate of $\mathrm{C}$ flux into storage pools via sinking fecal pellets and/or unconsumed detrital material (Franco-Santos et al. 2018). Selectivity by copepods like A. tonsa could have important consequences for the nutritional targets within food webs, and alter the nutritional geometric framework of communities (Raubenheimer and Simpson 2004, Simpson and Raubenheimer 2011). Phytoplankton assemblages in the field are even more diverse than the diatom mixtures used in our experiments, with respect to traits like prey size, motility and stoichiometric content, suggesting selective consumers like $A$. tonsa may likely have greater scope to reach their TER. Because consumers may use nutritional geometry and consume a variety of prey to meet their TER, single-species choice experiments may not be sufficient to predict ecosystem-level effects of consumers when prey communities are complex. 
Thus, copepods may survive and reach their target TER even in nutrient-poor conditions, so long as their prey varies both stoichiometrically and physically in some manner that allows for selectivity.

\section{ACKNOWLEDGEMENTS}

The authors would like to thank A. S. Tyrell, D. K. Padilla, and J. L. Collier for useful discussions. EMH was supported by an NSF-GRFP while performing this work as part of her Ph.D. dissertation. CLM was supported by the Bundesministerium für Bildung und Forschung (BMBF grant no. 01LN1702A), MB by the German Science Foundation within the Dynatrait programme. The authors would like to thank our reviewers for helpful comments.

\section{LITERATURE CITED}

Ågren, G. I. 2004. The C:N:P stoichiometry of autotrophs - Theory and observations. Ecology Letters 7:185191.

Anderson, T. R., D. O. Hessen, M. Boersma, J. Urabe, and D. J. Mayor. 2017. Will invertebrates require increasingly carbon-rich food in a warming world? American Naturalist 190:725-742.

Berggreen, U., B. Hansen, and T. Kiørboe. 1988. Food size spectra, ingestion and growth of the copepod Acartia tonsa during development: Implications for determination of copepod production. Marine Biology 99:341-352.

Boersma, M., and J. J. Elser. 2006. Too much of a good thing: On stoichiometrically balanced diets and maximal growth. Ecology 87:1325-1330.

Boersma, M., K. A. Mathew, B. Niehoff, K. L. Schoo, R. M. Franco-Santos, and C. L. Meunier. 2016. Temperature driven changes in the diet preference of omnivorous copepods: no more meat when it's hot? Ecology Letters 19:45-53.

Butler, N. M., C. A. Suttle, and W. E. Neill. 1989. Discrimination by freshwater zooplankton between single algal cells differing in nutritional status. Oecologia 78:368-372.

Chesson, J. 1978. Measuring preference in selective predation. Ecology 59:211-215.

Chesson, J. 1983. The estimation and analysis of preference and its relatioship to foraging models. Ecology 64:1297-1304.

Cowles, T. J., R. J. Olson, and S. W. Chisholm. 1988. Food selection by copepods: Discrimination on the basis of food quality. Marine Biology 100:41-49.

DeMott, W. R. 1989. Optimal foraging theory as a predictor of chemically mediated food selection by suspension-feeding copepods. Limnology and Oceanography 34:140-154.

Elser, J. J., D. R. Dobberfuhl, N. A. MacKay, and J. H. Schampel. 1996. Organism size, life history, and $\mathrm{N}: \mathrm{P}$ stoichiometry: Toward a unified view of cellular and ecosystem processes. BioScience 46:674-684.

Emlen, J. M. 1966. The role of time and energy in food preference. The American Naturalist 100:611-617.

Finkel, Z. V., J. Beardall, K. J. Flynn, A. Quigg, T. A. V. Rees, and J. A. Raven. 2009. Phytoplankton in a changing world: Cell size and elemental stoichiometry. Journal of Plankton Research 32:119-137.

Franco-Santos, R. M., H. Auel, M. Boersma, M. De Troch, C. L. Meunier, and B. Niehoff. 2018. Bioenergetics of the copepod Temora longicornis under different nutrient regimes. Journal of Plankton Research 40:420435.

Frost, B. W. 1972. Effects of size and concentration of food particles on the feeding behavior of the marine planktonic copepod Calanus pacificus . Limnology and Oceanography 17:805-815.

Frost, P. C., J. P. Benstead, W. F. Cross, H. Hillebrand, J. H. Larson, M. A. Xenopoulos, and T. Yoshida. 2006. Threshold elemental ratios of carbon and phosphorus in aquatic consumers. Ecology letters 9:774-779. 
Frost, P. C., M. A. Evans-White, Z. V Finkel, T. C. Jensen, and V. Matzek. 2005. Are you what you eat? Physiological constraints on organismal stoichiometry in an elementally imbalanced world. Oikos 109:18-28.

Guillard, R. R. L., and J. H. Ryther. 1962. Studies of marine planktonic diatoms. I. Cyclotella nana Hustedt, and Detonula confervacea (Cleve) Gran. Canadian Journal of Microbiology 8:229-239.

Hall, S. R. 2009. Stoichiometrically explicit food webs: Feedbacks between resource supply, elemental constraints, and species diversity. Annual Review of Ecology, Evolution, and Systematics 40:503-528.

Hansen, B., P. K. Bjørnsen, and P. J. Hansen. 1994. The size ratio between planktonic predators and their prey. Limnology and Oceanography 39:395-403.

Herstoff, E. M., S. B. Baines, M. Boersma, and C. L. Meunier. 2019. Does prey elemental stoichiometry influence copepod swimming and behavior over ontogeny? Limnology and Oceanography 64:2467-2477.

Huntley, M. E., K.-G. Barthel, and J. L. Star. 1983. Particle rejection by Calanus pacificus : Discrimination between similarly sized particles. Marine Biology 74:151-160.

Isari, S., M. Antó, and E. Saiz. 2013. Copepod foraging on the basis of food nutritional quality: Can copepods really choose? PLoS ONE 8:e84742.

Jakobsen, H. H., E. Halvorsen, B. W. Hansen, and A. W. Visser. 2005. Effects of prey motility and concentration on feeding in Acartia tonsa and Temora longicornis : The importance of feeding modes. Journal of Plankton Research 27:775-785.

Kiørboe, T. 2011. How zooplankton feed: Mechanisms, traits and trade-offs. Biological Reviews 86:311-339.

Kiørboe, T., E. Saiz, and M. Viitasalo. 1996. Prey switching behaviour in the planktonic copepod Acartia tonsa. Marine Ecology Progress Series 143:65-75.

Klein Breteler, W. C. M., N. Schogt, and S. Rampen. 2005. Effect of diatom nutrient limitation on copepod development: Role of essential lipids. Marine Ecology Progress Series 291:125-133.

Krebs, J. R., J. T. Erichsen, M. I. Webber, and E. L. Charnov. 1977. Optimal prey selection in the great tit (Parus major). Animal Behaviour 25:30-38.

Laidre, K. L., M. P. Heide-Jørgensen, and T. G. Nielsen. 2007. Role of the bowhead whale as a predator in West Greenland. Marine Ecology Progress Series 346:285-297.

Lavigne, D. M. 2003. Chapter 2: Marine mammals and fisheries: The role of science in the culling debate. Pages 31-47 in N. Gales, M. Hindell, and R. Kirkwood, editors. Marine Mammals- Fisheries, Tourism and Management Issues. First edition. CSIRO Publishing, Collingwood, Victoria, Australia.

Lehman, J. T. 1976. The filter-feeder as an optimal forager, and the predicted shapes of feeding curves. Limnology and Oceanography 21:501-516.

Libourel Houde, S. E., and M. R. Roman. 1987. Effects of food quality on the functional ingestion response of the copepod Acartia tonsa . Marine Ecology Progress Series 40:69-77.

Litchman, E., M. D. Ohman, and T. Kiorboe. 2013. Trait-based approaches to zooplankton communities. Journal of Plankton Research 35:473-484.

Litchman, E., P. de Tezanos Pinto, C. A. Klausmeier, M. K. Thomas, and K. Yoshiyama. 2010. Linking traits to species diversity and community structure in phytoplankton. Hydrobiologia 653:15-28.

MacArthur, R. H., and E. R. Pianka. 1966. On optimal use of a patchy environment. The American Naturalist 100:603-609.

Malzahn, A. M., and M. Boersma. 2012. Effects of poor food quality on copepod growth are dose dependent and non-reversible. Oikos 121:1408-1416. 
Meunier, C. L., M. Boersma, R. El-Sabaawi, H. M. Halvorson, E. M. Herstoff, D. B. Van De Waal, R. J. Vogt, and E. Litchman. 2017. From elements to function: Toward unifying ecological stoichiometry and trait-based ecology. Frontiers in Environmental Science 5:doi: 10.3389/fenvs.2017.00018 The.

Meunier, C. L., M. Boersma, K. H. Wiltshire, and A. M. Malzahn. 2016. Zooplankton eat what they need: copepod selective feeding and potential consequences for marine systems. Oikos 125:50-58.

Meunier, C. L., F. M. Hantzsche, A. O. Cunha-Dupont, J. Haafke, B. Oppermann, A. M. Malzahn, and M. Boersma. 2012. Intraspecific selectivity, compensatory feeding and flexible homeostasis in the phagotrophic flagellate Oxyrrhis marina: Three ways to handle food quality fluctuations. Hydrobiologia 680:53-62.

Meunier, C. L., A. M. Malzahn, and M. Boersma. 2014. A new approach to homeostatic regulation: Towards a unified view of physiological and ecological concepts. PLoS ONE 9:e107737.

Meunier, C. L., K. Schulz, M. Boersma, and A. M. Malzahn. 2013. Impact of swimming behaviour and nutrient limitation on predator-prey interactions in pelagic microbial food webs. Journal of Experimental Marine Biology and Ecology 446:29-35.

Miller, C. A., and M. R. Roman. 2008. Effects of food nitrogen content and concentration on the forms of nitrogen excreted by the calanoid copepod, Acartia tonsa. Journal of Experimental Marine Biology and Ecology 359:11-17.

Mitra, A., C. Castellani, W. C. Gentleman, S. H. Jonasdottir, K. J. Flynn, A. Bode, C. Halsband, P. Kuhn, P. Licandro, M. D. Agersted, A. Calbet, P. K. Lindeque, R. Koppelmann, E. F. Moller, A. Gislason, T. Gissel Nielsen, and M. St. John. 2014. Bridging the gap between marine biogeochemical and fisheries sciences; configuring the zooplankton link. Progress in Oceanography 129:176-199.

Montagnes, D. J. S., and D. J. Franklin. 2001. Effect of temperature on diatom volume, growth rate, and carbon and nitrogen content: Reconsidering some paradigms. Limnology and Oceanography 46:2008-2018.

Mullin, M. M. 1963. Some factors affecting the feeding of marine copepods of the genus Calanus . Limnology and Oceanography 8:239-250.

Pinheiro, J., D. Bates, S. DebRoy, D. Sarka, and The R Core Team. 2020. nlme: Linear and Nonlinear Mixed Effects Models. R.

Plath, K., and M. Boersma. 2001. Mineral limitation of zooplankton: Stoichiometric constraints and optimal foraging. Ecology 82:1260-1269.

Poulet, S. A., and P. Marsot. 1978. Chemosensory grazing by marine calanoid copepods (Arthropoda: Crustacea). Science 200:1403-1405.

Quigg, A., Z. V Finkel, A. J. Irwin, Y. Rosenthal, T.-Y. Ho, J. R. Reinfelder, O. Schofield, F. M. M. Morel, and P. G. Falkowski. 2003. The evolutionary inheritance of elemental stoichiometry in marine phytoplankton. Nature 425:291-294.

Raubenheimer, D., and S. A. Jones. 2006. Nutritional imbalance in an extreme generalist omnivore: Tolerance and recovery through complementary food selection. Animal Behaviour 71:1253-1262.

Raubenheimer, D., and S. J. Simpson. 1997. Integrative models of nutrient balancing: Application to insects and vertebrates. Nutrition Research Reviews 10:151-179.

Raubenheimer, D., and S. J. Simpson. 2004. Organismal stoichiometry: Quantifying non-independence among food components. Ecology 85:1203-1216.

Richman, S., and J. N. Rogers. 1969. The feeding of Calanus helgolandicus on synchronusly growing populations of the marine diatoms Ditylum brightwellii . Limnology and Oceanography 14:701-709. 
Saiz, E., K. Griffell, A. Calbet, and S. Isari. 2014. Feeding rates and prey:predator size ratios of the nauplii and adult females of the marine cyclopoid copepod Oithona davisae. Limnology and Oceanography 59:2077-2088.

Simpson, S. J., and D. Raubenheimer. 2011. The nature of nutrition: A unifying framework. Australian Journal of Zoology 59:350-368.

Simpson, S. J., R. M. Sibly, K. P. Lee, S. T. Behmer, and D. Raubenheimer. 2004. Optimal foraging when regulating intake of multiple nutrients. Animal Behaviour 68:1299-1311.

Siuda, A. N. S., and H. G. Dam. 2010. Effects of omnivory and predator-prey elemental stoichiometry on planktonic trophic interactions. Limnology and Oceanography 55:2107-2116.

Sokal, R. R., and F. J. Rohlf. 2012. Biometry: The principles and practice of statistics in biological research. Fourth edition. W.H. Freeman and Company, New York.

Steinberg, D. K., S. A. Goldthwait, and D. A. Hansell. 2002. Zooplankton vertical migration and the active transport of dissolved organic and inorganic nitrogen in the Sargasso Sea. Deep Sea Research I 49:1445-1461.

Sterner, R. W., and J. J. Elser. 2002. Ecological stoichiometry: The biology of elements from molecules to the biosphere. Princeton University Press, Princeton NJ.

Stoecker, D. K., and N. K. Sanders. 1985. Differential grazing by Acartia tonsa on a dinoflagellate and a tintinnid. Journal of Plankton Research 7:85-100.

Stottrup, J. G., and J. Jensen. 1990. Influence of algal diet on feeding and egg-production of the calanoid copepod Acartia tonsa Dana. Journal of Experimental Marine Biology and Ecology 141:87-105.

Strathmann, R. 1967. Estimating the organic carbon content of phytoplankton from cell volume or plasma volume. Limnology and Oceanography 12:411-418.

Tao, L., A. R. Berns, and M. D. Hunter. 2014. Why does a good thing become too much? Interactions between foliar nutrients and toxins determine performance of an insect herbivore. Functional Ecology 28:190196.

The R Core Team. 2013. R: A Language and Environment for Statistical Computing. R Foundation for Statistical Computing, Vienna, Austria.

Turner, J. T. 2004. The importance of small pelagic planktonic copepods and their role in pelagic marine food webs. Zoological Studies 43:255-266.

Tyrell, A. S., and N. S. Fisher. 2019. Separating viscous and thermal effects of temperature on copepod feeding. Journal of Plankton Research 41:865-878.

Urabe, J., and Y. Watanabe. 1992. Possibility of N or P limitation for planktonic cladocerans: An experimental test. Limnology and Oceanography 37:244-251.

Wirtz, K. W. 2012. Who is eating whom? Morphology and feeding type determine the size relation between planktonic predators and their ideal prey. Marine Ecology Progress Series 445:1-12.

Wishner, K., E. Durbin, A. Durbin, M. Macaulay, H. Winn, and R. Kenney. 1988. Copepod patches and right whales in the Great South Channel off New England. Bulletin of Marine Science 43:825-844.

$\mathrm{Xu}, \mathrm{Y}$., and W. X. Wang. 2003. Fates of diatom carbon and trace elements by the grazing of a marine copepod. Marine Ecology Progress Series 254:225-238.

Zhou, L., and S. A. J. Declerck. 2019. Herbivore consumers face different challenges along opposite sides of the stoichiometric knife-edge. Ecology Letters 22:2018-2027.

Table 1: Size and stoichiometric composition of diatoms. The means of the equivalent spherical diameters (ESD), C, N, and C:N composition are shown (+-1 SE). For all, $\mathrm{n}=3$ samples. A one-way ANOVA 
was performed; the dependent variables are listed within each column, and the independent variables were the diatom species and condition. The results of post-hoc Tukey-Kramer test performed after each ANOVA are shown as letters within superscripts in each column.

Table 2: Results of analyses of variance of grazing experiments. Diatoms were either Thalassiosira weissflogii(Large) or T. pseudonana (Small), and were reared in either nutrient-replete (R) or N-deficient media $(-\mathrm{N})$. Three grazing trials with nine replicates each were run (overviewed in Fig. 1). Because a series of comparisons with expected outcomes were planned, we performed Welch's t-tests on the focal groups shown. We asked whether there were significant differences in the grazing rate of $\mathrm{C}$ and $\mathrm{N}\left(\mu \mathrm{g}\right.$ copepod $\left.{ }^{-1} \mathrm{~h}^{-1}\right)$, and in the ingestion rate, i (cells copepod ${ }^{-1} \mathrm{~h}^{-1}$ ). We analyzed these data both when considering diatoms of the same species and ignoring rearing condition, and when considering diatoms from the same rearing condition and ignoring species identity. For all, means $( \pm 1 \mathrm{SE})$ where $\mathrm{n}=9$ and bolded $\mathrm{p}>0.05$. The results presented in this table are shown in Figs. 2-3.

Table 1.

\begin{tabular}{llllll}
\hline Diatom spp. & Condition & $\mathbf{E} \boldsymbol{\Sigma} \boldsymbol{\Delta}(\boldsymbol{\mu \mu})$ & $\mathbf{C}\left(\mathbf{p g}\right.$ cell $\left.^{\mathbf{- 1}}\right)$ & $\mathbf{N}\left(\mathbf{p g}\right.$ cell $\left.^{\mathbf{1}}\right)$ & $\mathbf{C : N}(\mathbf{m o l}: \mathbf{m o l})$ \\
\hline T. pseudonana & N-deficient & $4.14(0.012)^{\mathrm{a}}$ & $24.09(1.35)^{\mathrm{a}}$ & $2.65(0.06)^{\mathrm{a}}$ & $10.56(0.51)^{\mathrm{a}}$ \\
& Replete & $4.19(0.008)^{\mathrm{a}}$ & $20.16(0.81)^{\mathrm{a}}$ & $3.35(0.09)^{\mathrm{b}}$ & $7.13(0.33)^{\mathrm{b}}$ \\
T. weissflogii & N-deficient & $12.28(0.031)^{\mathrm{b}}$ & $319.98(11.95)^{\mathrm{b}}$ & $33.5(1.65)^{\mathrm{c}}$ & $11.79(0.85)^{\mathrm{a}}$ \\
& Replete & $13.28(0.18)^{\mathrm{c}}$ & $389.92(30.27)^{\mathrm{b}}$ & $89.29(3.18)^{\mathrm{d}}$ & $5.01(0.24)^{\mathrm{c}}$ \\
\hline
\end{tabular}

Table 2.

\begin{tabular}{|c|c|c|c|c|c|c|c|c|}
\hline Grazing trial & Focus & Diatom & Quality & Mean & $\pm 1 \mathrm{SE}$ & Within species & Within species & Within species \\
\hline & & & & & & $\mathrm{t}$ & d.f. & $\mathrm{p}$ \\
\hline \multirow[t]{12}{*}{ Single species } & \multirow[t]{4}{*}{$\mathrm{C}$} & Large & $-\mathrm{N}$ & 112.00 & 33.30 & Within Large: & Within Large: & Within Large: \\
\hline & & Large & $\mathrm{R}$ & 39.80 & 9.03 & 2.1 & 9.17 & 0.032 \\
\hline & & Small & $-\mathrm{N}$ & 7.96 & 3.40 & Within Small: & Within Small: & Within Small: \\
\hline & & Small & $\mathrm{R}$ & 4.70 & 2.31 & 0.79 & 14.10 & 0.22 \\
\hline & \multirow[t]{4}{*}{$\mathrm{N}$} & Large & $-\mathrm{N}$ & 11.80 & 3.48 & Within Large: & Within Large: & Within Large: \\
\hline & & Large & $\mathrm{R}$ & 3.09 & 0.70 & 2.44 & 8.65 & 0.98 \\
\hline & & Small & $-\mathrm{N}$ & 1.11 & 0.47 & Within Small: & Within Small: & Within Small: \\
\hline & & Small & $\mathrm{R}$ & 0.62 & 0.30 & 0.87 & 13.65 & 0.20 \\
\hline & \multirow[t]{4}{*}{$\mathrm{i}$} & Large & $-\mathrm{N}$ & 1732 & 512 & Within Large: & Within Large: & Within Large: \\
\hline & & Large & $\mathrm{R}$ & 508 & 109 & 2.33 & 8.73 & 0.023 \\
\hline & & Small & $-\mathrm{N}$ & 1531 & 651 & Within Small: & Within Small: & Within Small: \\
\hline & & Small & $\mathrm{R}$ & 1108 & 520 & 0.51 & 15.24 & 0.31 \\
\hline \multirow[t]{12}{*}{ Size-selective } & \multirow[t]{4}{*}{$\mathrm{C}$} & Large & $-\mathrm{N}$ & 100.00 & 8.17 & Within Large: & Within Large: & Within Large: \\
\hline & & Large & $\mathrm{R}$ & 36.00 & 11.50 & 4.57 & 14.47 & 2.01E-04 \\
\hline & & Small & $-\mathrm{N}$ & 1.49 & 1.40 & Within Small: & Within Small: & Within Small: \\
\hline & & Small & $\mathrm{R}$ & 0.01 & 0.01 & 1.05 & 8.00 & 0.16 \\
\hline & \multirow[t]{4}{*}{$\mathrm{N}$} & Large & $-\mathrm{N}$ & 10.50 & 0.86 & Within Large: & Within Large: & Within Large: \\
\hline & & Large & $\mathrm{R}$ & 2.80 & 0.89 & 6.24 & 15.98 & $5.89 \mathrm{E}-06$ \\
\hline & & Small & $-\mathrm{N}$ & 0.21 & 0.20 & Within Small: & Within Small: & Within Small: \\
\hline & & Small & $\mathrm{R}$ & 0.00 & 0.00 & 1.05 & 8 & 0.16 \\
\hline & \multirow[t]{4}{*}{$\mathrm{i}$} & Large & $-\mathrm{N}$ & 2291 & 515 & Within Large: & Within Large: & Within Large: \\
\hline & & Large & $\mathrm{R}$ & 563 & 189 & 3.15 & 10.11 & $5.12 \mathrm{E}-03$ \\
\hline & & Small & $-\mathrm{N}$ & 836 & 811 & Within Small: & Within Small: & Within Small: \\
\hline & & Small & $\mathrm{R}$ & 3 & 3 & 1.03 & 8.00 & 0.17 \\
\hline Size $\times$ stoichiometry & $\mathrm{C}$ & Large & $-\mathrm{N}$ & 0 & 0 & Within Large: & Within Large: & Within Large: \\
\hline
\end{tabular}




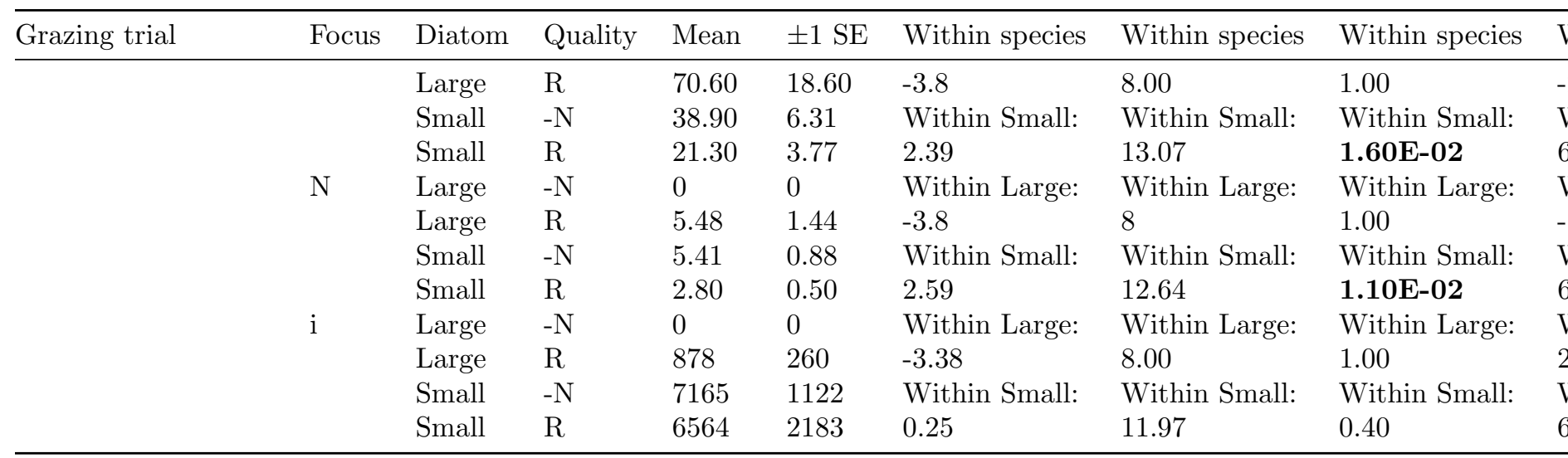

A.

\begin{tabular}{|c|c|c|}
\hline \multicolumn{3}{|c|}{ Single species grazing } \\
\hline $\begin{array}{l}\text { Small, Replete } \\
0.32( \pm 0.011)\end{array}$ & & $\begin{array}{c}\text { Small, N-deficient } \\
0.36( \pm 0.0088)\end{array}$ \\
\hline $\begin{array}{l}\text { Large, Replete } \\
2.99( \pm 0.057)\end{array}$ & & $\begin{array}{l}\text { Large, W-deftaient } \\
2.31( \pm 0.024)\end{array}$ \\
\hline
\end{tabular}

B.

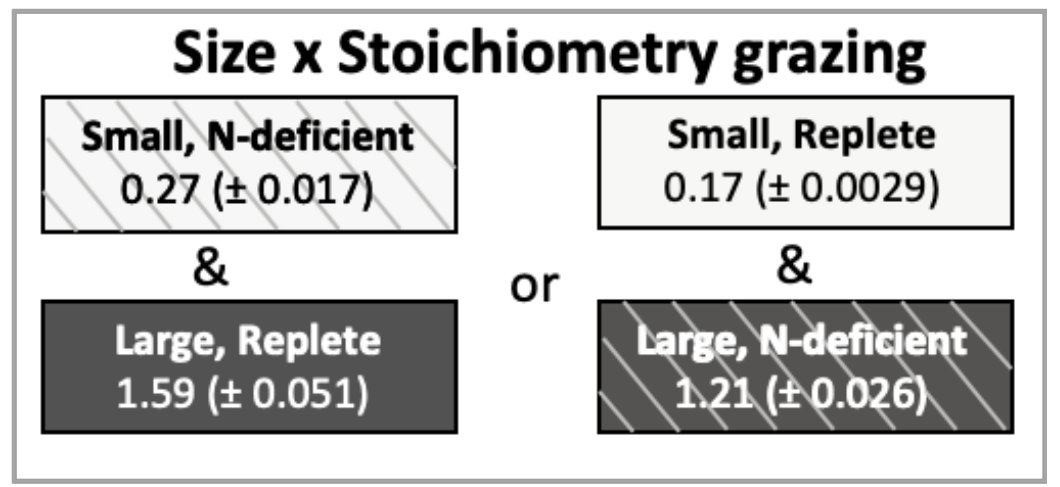

C.

\begin{tabular}{|c|c|c|}
\hline \multicolumn{3}{|c|}{ Size-selective grazing } \\
\hline $\begin{array}{c}\text { Small, N-deficient } \\
0.24( \pm 0.014)\end{array}$ & \multirow{3}{*}{ or } & $\begin{array}{l}\text { Small, Replete } \\
0.19( \pm 0.0081)\end{array}$ \\
\hline$\&$ & & \& \\
\hline $\begin{array}{l}\text { barge, W-deftaicht } \\
121( \pm 0.019)\end{array}$ & & $\begin{array}{l}\text { Large, Replete } \\
1.50( \pm 0.044)\end{array}$ \\
\hline
\end{tabular}


Figure 1: Overview of experimental setup. Colored-coded rectangles indicate diatom species ("Small", light grey $=$ Thalassiosira pseudonana , "Large", dark grey $=T$. weissflogii ) and stoichiometric rearing condition $(\mathrm{N}$-deficient media $=$ hatched boxes, Replete media $=$ solid boxes). Average diatom density

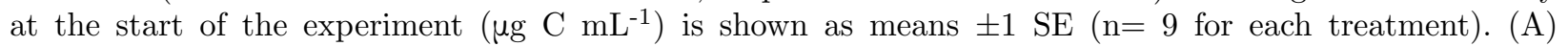
In single species grazing trials, each of the four diatom types was offered individually to copepods. This resulted in four separate treatments. (B) In size $\times$ stoichiometry grazing trials, pairs of diatoms of different sizes and from different rearing conditions, were simultaneously offered to copepods. This resulted in two separate treatments. (C) In size-selective grazing trials, pairs of diatoms of different sizes, but from the same stoichiometric rearing condition, were simultaneously offered to copepods. This resulted in two separate treatments. 


\section{Single species grazing}
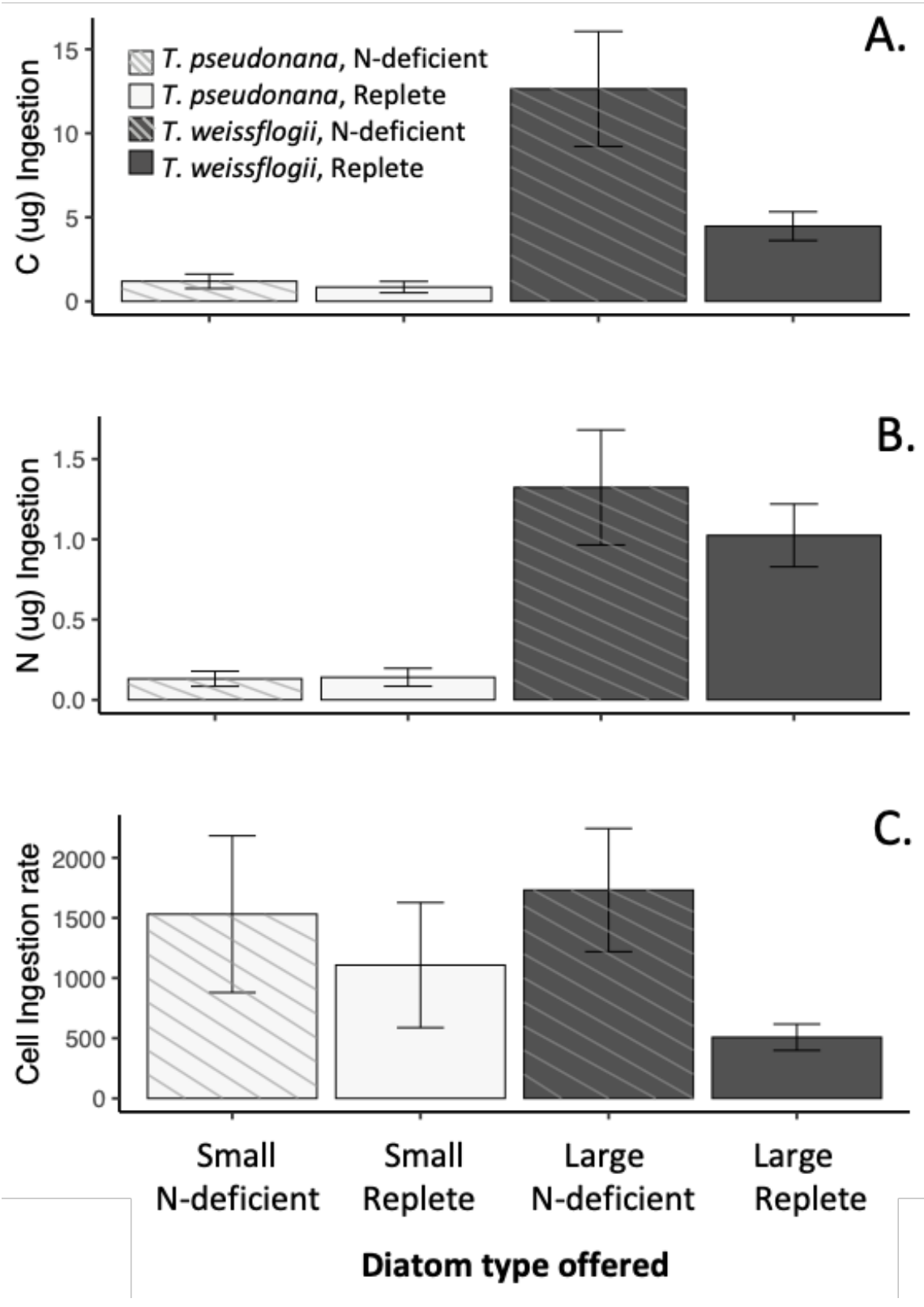

Figure 2: Results of single species grazing trials. Bars show means \pm 1 SE ( $\mathrm{n}=9$ per experiment) for grazing rate of (A) C ( $\mu$ copepod $^{-1}$ hour $\left.^{-1}\right)$, of (B) N ( $\mu$ copepod $^{-1}$ hour $\left.^{-1}\right)$, and (C) cell ingestion rate (cells copepod $^{-1}$ hour $^{-1}$ ). Bar color indicates diatom type offered to copepods, as overviewed in Fig. 1, and as indicated on the horizontal axis. 

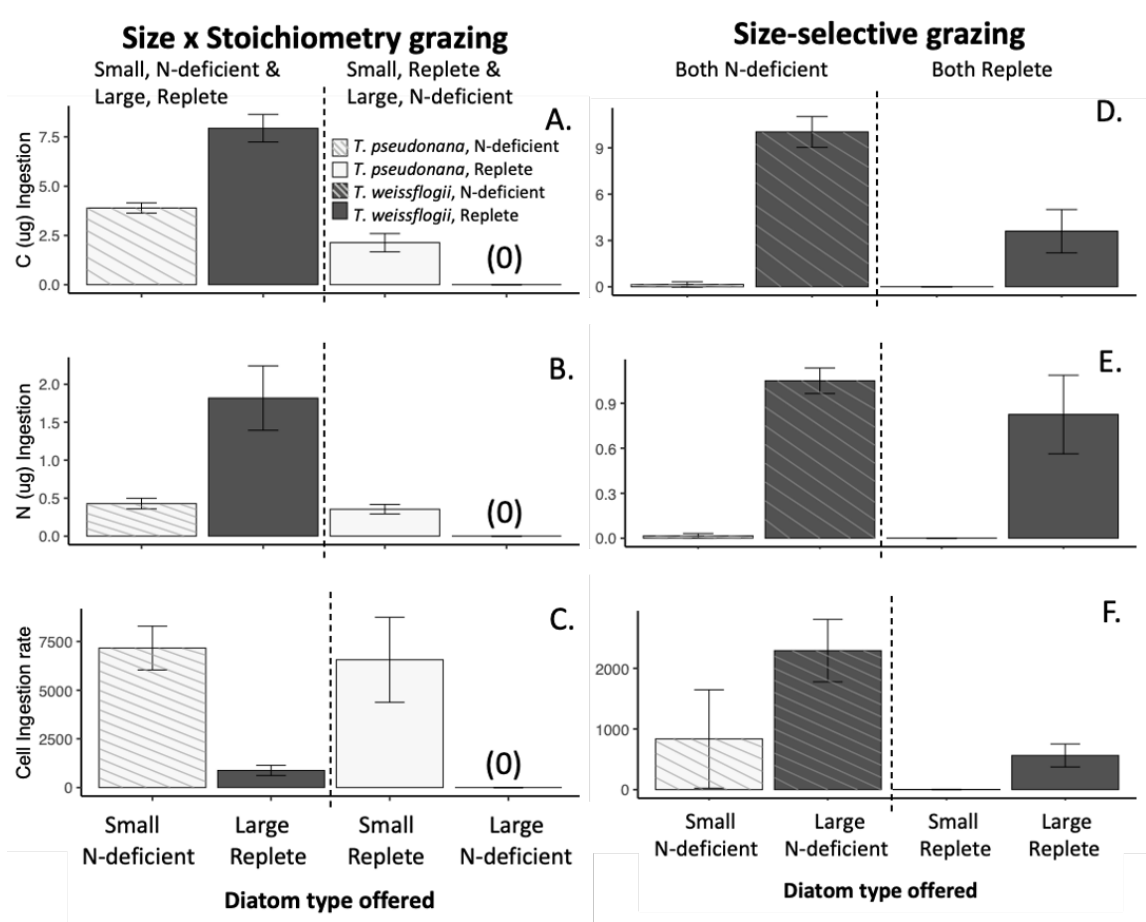

Figure 3: Results of selectivity trials. Bars show means $\pm 1 \mathrm{SE}$ ( $\mathrm{n}=9$ per experiment) for grazing of $(\mathrm{A}, \mathrm{D}) \mathrm{C}\left(\mu \mathrm{g}\right.$ copepod $^{-1}$ hour $\left.^{-1}\right),(\mathrm{B}, \mathrm{E}) \mathrm{N}\left(\mu \mathrm{g}\right.$ copepod $^{-1}$ hour $\left.^{-1}\right)$, and $(\mathrm{C}, \mathrm{F})$ the cell ingestion rate (cells copepod $^{-1}$ hour $\left.^{-1}\right)$. Bar color indicates diatom type offered during experiments, as overviewed in Fig. 1, and as indicated on the horizontal axis. Dashed vertical lines separate results for each of the diatom pairs offered. Note the different scales on the y-axes. 


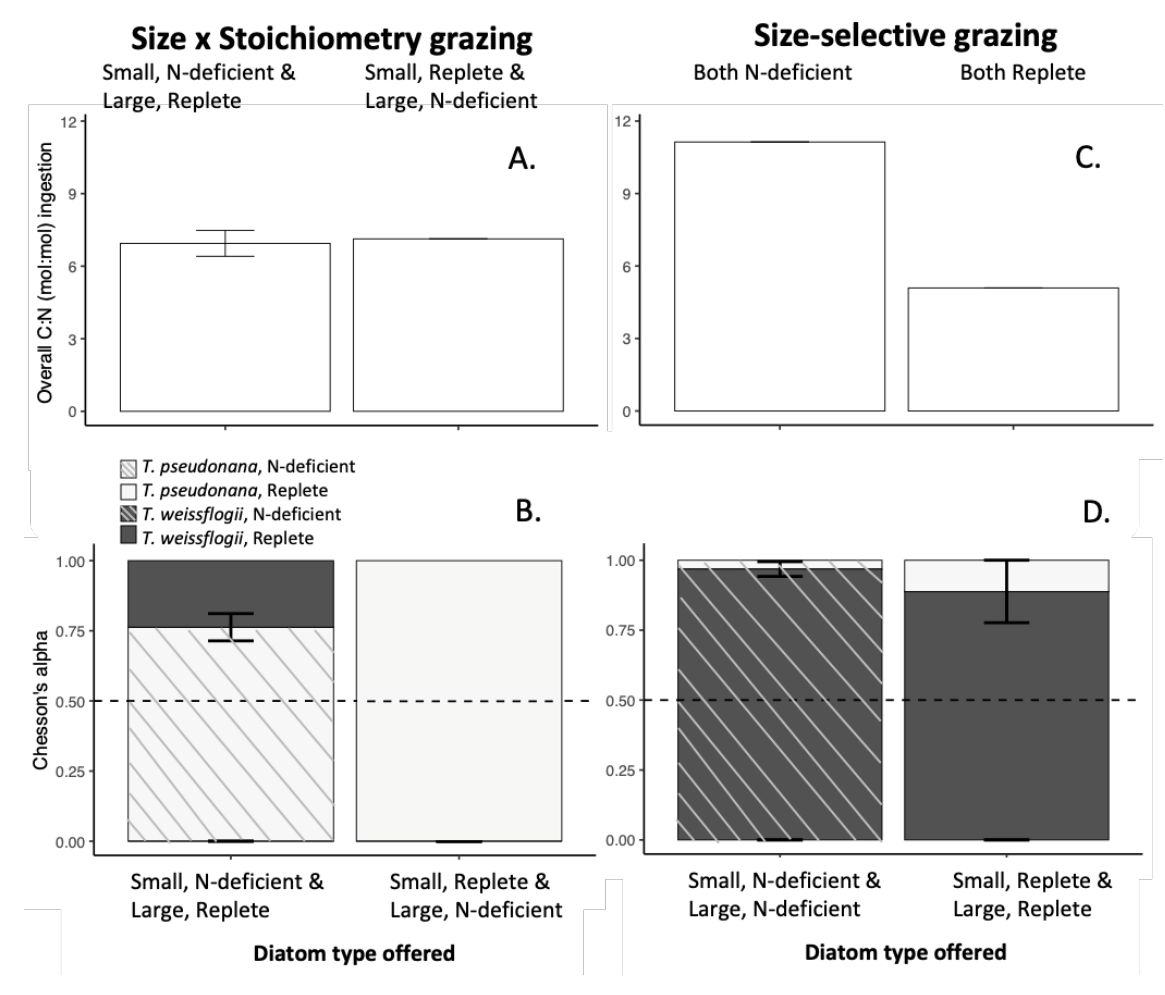

Figure 4: Overall C:N ingested, and Chesson's selectivity index for $\mathrm{C}$ ingested by copepods in selectivity experiments. Diatom mixtures offered as overviewed in Fig. 1, and indicated on the horizontal axis. (A, C) The overall C:N ingested when consuming both diatoms in a mixture. White bars show means $\pm 1 \mathrm{SE}$ ( $\mathrm{n}=9$ per experiment). (B, D) Chesson's selectivity index for $\mathrm{C}$ ingested; bar height represents the mean observed $\alpha \pm 1 \mathrm{SE}(\mathrm{n}=9)$. Diatom types grazed type indicated by legend inset. The dashed line represents the expected $\alpha$ of 0.5 . 